\title{
APOLOGIA CORRUPTION VS PUNITIVE RESPONSES: A CONTENT ANALYSIS AND AN EXPERIMENTAL STUDY ON APOLOGIA STRATEGY OF THE SUSPECTED CORRUPTORS AND THE PUBLIC RESPONSES
}

\author{
Kriyantono Rachmat \\ School of Communication, University of Brawijaya, Malang, Indonesia \\ E-mail: rachmat kr@ub.ac.id
}

\begin{abstract}
Apologia and Attribution theories are used to explain whether the apologia strategies of the suspected corruption affect the public's punitive responses in crisis situation. Attribution theory suggests that every individual or institution may be criticized for their actions and suggests the possible consequences of attribution on punitive responses. Apologia theory suggests anticipative strategies for possible accusations to gain positive attribution. This research applies a content analysis on 50 news containing the apologia strategies of the corruption actors published in online media and an experiment on 100 participants to measure whether the strategies influencing the public's punitive responses. The findings indicate that both actors, the caught and the suspects, use predominantly bolstering strategies. Bolstering strategy results in much higher sympathy for both actors and reduces the public's punitive responses against the actors although it is not likely to completely remove the public anger.
\end{abstract}

\section{KEY WORDS}

Apologia, attribution, corruption, crisis, public relations.

Apologia theory (1973) and Weiner's attribution theory (2006) can be useful frameworks for crisis research. Apologia strategies are applied by individuals and their organizations to defend themselves when they are accused of corruption, "the accused chose to face his accusers and to speak in defending of himself" (Ware \& Linkugel, 1973, p. 273 ) in order to gain good impression from other people (Goffman, 1959). The theory has moved from not only serving as a guide for individuals to be absolved but also for organizations in crisis since the organization has a reputation that has a chance of attack from the outside so that management can do self-defence to respond it (Coombs, 2015; Coombs \& Holladay, 2011; Hearit, 2006; Hoffmann \& Barnett, 2015; Kriyantono \& McKenna, 2019). Furthermore, the organizational reputation is also affected by the good or bad behaviour of individual members because the organization is a unified system (Kriyantono, 2017). The interrelationship between organizations and individuals regarding the apologia strategy is called the apologia of association (Roberson \& Connaughton, 2010). Hence, it is interesting to evaluate the effect of the individuals and organizations' apologia strategies toward the public's punitive responses.

This research contributes to filling the void of applying apologia and attribution theories in corruption cases in Indonesia by confirming the premise of both theories in individuals accused of corruption, both corruption suspects who arrested while committing corruption and suspects who were not caught red-handed. It is also important since the level of corruption in Indonesia is still below from the median level and the effort to wipe out corruption seems run slowly since the corruption perception index rises only five point from 32 to 37 during 2012-2017, with the interval between 0-100 (Kriyantono, Destrity, Amrullah \& Rakhmawati, 2017), and is on the rank of 90 from 176 nations (Toriana, 2017). In addition to Lehmberg \& Hicks's (2018) findings that apologia strategy differs among countries, the research contributes to the growth of public relations theories and practices in Indonesia context since public relations study has been dominated by Western perspective (Kriyantono \& McKenna, 2017). 


\section{LITERATURE REVIEW}

Apologia is rooted in a rhetorical genre that refers to self-defence (Coombs, Frandsen, Holladay \& Johansen, 2010; Ware \& Linkugel, 1973). Ware and Linkugel (1973) views apologia as speak of self-defence to respond to the attack of the character it receives, which includes the questioning of man's moral nature, motives, and reputation. These questions are linked to Downey's (1993) definition of apologia as a character defence rather than the defence of policies and ideas (Cited in Arendt, LaFleche, \& Limperopulos, 2017). Individuals and organizations may be criticized for their actions, and how to respond is a form of communication known as apologia (Heath, 2013). Apologia theory originated in the defence of an individual (Ware \& Linkugel, 1973), but some literature affirms that it has evolved in offering solutions for the organizations in dealing with the accusations during a crisis as a crisis communication strategy (Chikudate, 2010; Coombs, 2015; Coombs et al., 2010; Hearit, 1995, 1995; Kriyantono \& McKenna, 2019; Seeger \& Sellnow, 2016). A meta-analysis on articles of 51 journals from 1986-2016 reveals that apologia has been applied in image repair and crisis communication literature (Arendt et al. 2017).

As a crisis communication strategy, apologia has been applied to restore the reputation (Stewart, 2008) since the crisis threatens the reputation of the individual or company so that a defence attitude is required (Coombs et al., 2010). Apologia theory is also text-oriented and it learns what and how individuals and organizations communicate when the crisis strikes its image or reputation (Coombs \& Holladay, 2010). Crises are unexpected events that create uncertainty and endanger the image, identity, or reputation of individuals or companies (Fearn-Banks, 2017; Kriyantono \& McKenna, 2019; Taneja, Pryor, Sewell, S, \& Recuero, 2014). Individuals and companies are faced with various crisis potentials, such as technological crises, confrontations, malevolence, natural disasters, products, and management (Coombs et al., 2010; Kriyantono, 2015), which stimulate the emergence of public attribution of who should be responsible (Coombs, 2015; Kriyantono, 2012).

Attribution theory predicts that public is more likely to punish an actor when the actor is attributed guilty (Weiner, 2006). As a result, a proper strategy is needed to manage public perceptions of crisis, image, and reputation (Coombs, 2010; Knoespel, 2009). In this point, apologia posits an important role since "apologia strategies provide the basis for articulating crisis response strategies, ways to categorize what manager said and did after a crisis" (Coombs, 2010, p. 340).

The concept of self-defence in apologia looks at the types of allegations and facts (Hearit, 1995; Heath, 2013; \& Seeger \& Sellnow, 2016), therefore, apologia has four strategies: Denial that denies the allegations and considers the allegations wrong; Bolstering that focuses on the positive, strength, and advantages of past relationships; Differentiation aims to change the meaning of the audience about the crisis; and the transcendence that defines the context in the form which is wider and abstract (Ware \& Linkugel, 1973; Coombs et al, 2010; Heath, 2013; Jarvis, 2016).

The process of attribution is preceded by certain considerations before the individual attributes to a thing (Weiner, 2006). These considerations according to McDermot (2009) are influenced by three things: (1) consensus, which is a habit commonly done by certain people in a group to become a collective agreement, (2) consistency, assessment of individual behavioural tendencies (3) Distinctiveness, an attribution process based on behavioural diversity in different situations. These three considerations essentially derive on basic assumptions of attribution theory: The individuals have a tendency to find out and to explain the cause of an crisis event, the attribution will affect each individual's responses in the next situation, and the individuals have reasons to build the impression or judgment on other people (Heath, 2005; McDermott, 2009).

It can be concluded that there is a link between individual attributions and punitive responses, that is, punitive responses are strongly influenced by emotional factors such as anger and sympathy which will also determine the type of attributions to a particular phenomenon (Palmieri \& Peterson, 2009; Weiner, 2006). Furthermore, Weiner (2006) states 
that the emotions starts from the process of interpreting the event that is driven by the individuals' desire to find out what happened.

The media frame determines the public's emotional reactions to support or punish other individuals or organizations that are experiencing a crisis (Tennert, 2014). Therefore, this research evaluates the media news to determine the apologia strategies from the suspects.

Corruption is a crime involving ongoing coordination between various agencies (Palmer \& Michael, 2006). Corruption is a massive problem in many countries, especially in developing countries, including Indonesia (Kriyantono, et al., 2017). In Indonesia, "because of many cases conducted, corruption is known as its own culture" (Pratomo \& Kriyantono, 2016, p.5). There are interesting findings from The Indonesia Corruption Watch that most corruptors come from government apparatus (Egi, 2016). Corruption committed by government officials has a huge impact because it threatens the identity and reputation of either the individuals or their institutions (Waymer \& Heath, 2007; Kriyantono et al., 2015).

Apologia can be applied in areas such as business (Hearit \& Brown, 20014), sports (Glantz, 2010), and politics (Kiambi, 2012). This current research applies apologia theory in the field of corruption since the corruptors communicate to defend themselves from the allegation. This corruption will encourage public attribution related to responsible perpetrators (Benoit, 1995). Apologia strategy, thus, can be used as communication crisis tools to reduce the level of negative emotions experienced by the public (Coombs et al., 2010).

Several studies have been conducted to evaluate apologia as crisis response strategies. Tollefson (2000) compares Newsweek's apology strategy and its editor, Klein, in responding to allegations of falsehood related to anonymous authorship identity cases to boost sales. Klein uses a denial strategy to regard accusations based only on gossip and his actions are not a big deal. Klein also uses a differentiation strategy, which declares himself as a victim when he has violated the journalist's ethical code. While Newsweek as an organization expressed regret for Klein's actions and promised not to damage public confidence again. Tollefson (2000) finds Newsweek's strategy is more effective at muffling controversy and public anger than Klein's denying strategy despite evidence that he was guilty.

Hearit and Brown (2004) also examines the crisis of uncovering evidence of business fraud that befell Merrill Lynch. Merrill Lynch tends to use denial and scapegoating strategies rather than expressing regret to dampen public anger. Merrill Lynch's strategy cannot maintain its reputation because there is undeniable evidence that the company is guilty although in the end Merrill Lynch paid a fine of 100 million dollars as a consequence of his fraudulent actions. Kiambi (2011) examines Kenyan law minister apologia strategy. The minister faces allegations of contempt for women due to her controversial remarks, admits his mistake and apologizes for stifling the women's group protests in Kenya. In the next government, he was again appointed to minister because his reputation was maintained.

Glantz (2010) who analysed the crisis response of American bicycle athlete Floyd Landis who was accused of using doping to win the Tour De France race concludes that differentiation and denial strategies cannot sustain Landis's reputation since the urine test proves the athlete consumes the synthetic testosterone. Landis's doctor uses a bolstering strategy by promoting how hard Landis worked, but, this strategy did not work because the public judged Kay's doctor to have personal affinity with Landis.

It can be concluded that a guilty individual or organization is incapable of defending its reputation in crisis when using denial strategies and bolstering strategy depends on the credibility of the third party. It reinforces Harris's (2006) opinion that apologies and accountability statements become mandatory features of apologia which are applied in all languages and situations.

On the other hand, some studies (Benoit 1995, \& Coombs, 1995) suggest that denial strategies may be effective in protecting reputation if this strategy can show the public that no crisis has occurred. This can happen because, referring to Regester \& Larkin (2008), perception is reality, and reality in crisis is built from public perceptions. Denial strategies are not always unsuccessful to implement, effective denials to maintain a crisis-time reputation in 
a particular scenario or situation (Vand der Meer, 2014). According to Towner (2009, p. 439), "a denial of an allegation or fact functions as a useful strategy (as long as the truth is not distorted)..."

Coombs, Holladay and Claeys (2016) have proved that individuals or organizations that use denial and then found not guilty can keep their reputations in good standing and lower public anger. Denial is a strategy or claim that is subject to verification, "denial should be effective only if the organization bears no responsibility for the crisis" (Coombs, Holladay \& Claeys, 2016. h. 385). Therefore, it can be concluded that individuals or organizations that are not proven guilty tend to be able to maintain their reputation in crisis when using denial strategy.

In the case of corruption, there are two situations related to the aspects of evidence of guilt: the caught and the suspect. According to the Indonesian Law Regulation, the caught is a person who was arrested while committing a crime (in hand arrest). The suspect is a person who, by his actions or his circumstances based on preliminary evidence, is suspected of being a criminal offender. It can be said that the caught has a greater potential to affect the individual's reputation.

Based on Goffman (1959) and Johansen (2007), individuals intentionally use verbal and nonverbal communication to manage the impression of others on the individual's self when interacting with others. "All symbols such as clothing worn, walking, and talking are used for self-presentation in order to get a positive impression from others" (Kriyantono, 2017, p.222). The statements of corruption suspects, as apologia strategies, are widely communicated through the mass media to the public. Therefore, the researchers formulate the propositions:

P1: The caught tends not to use the denial strategy predominantly to maintain reputation in times of crisis.

P2: The suspect tends to use the denial strategy predominantly to maintain reputation in times of crisis.

Apologia research is seen as a sender oriented because it focuses on how the sender chooses a message to be communicated to the public (Coombs et al., 2010; Lee, 2004, 2005), however, researcher argue that it is important to measure the effectiveness of apologia strategies in maintaining the reputation of individuals or organizations. Apologia is said to succeed if individuals or organizations can articulate their behaviour from allegations of abuse and apologize, and show a corrective process because apologia is not just a word (Hearit \& Brown, 2004). The aim of apologia is not to accept forgiveness (Hearit, 2006), but 'to avoid punishment and reputation damage' (Lazare, 2004). In addition, apologia strategies which are spread across the mass media can influence public attributions and enable the emergence of punitive responses (Jeong, 2009; Kriyantono, Riani, \& Safitri, 2016), therefore, the researcher formulates proposition 3:

P3: Public tends to provide punitive responses for the caught.

\section{METHODS OF RESEARCH}

The research applied both content analysis and experiment. Content analysis was applied to measure the actors' strategies and experiment was implemented to measure the public's responses.

A content analysis is used to prove propositions one and two, while an experiment is used to test third propositions. Online media is chosen because "people are now more into online and audio-visual media" (Tapsell, 2014, p.184) so that this online exposure will likely to determine public's attribution. Furthermore, content analysis has been used to study the content of document, such as newspapers, reports, social networking sites and similar media (Kriyantono, 2014). This study analyses the quote news from the corruption suspects cited by kompas.com, a top brand in online news category (lka, 2016).

The researchers chose corruption cases that received public attention for dominating media coverage during 2012-2018. The caught red-handed actor was the chief of United Development Party (2019), while the not caught red-handed actor was involving the General 
Secretary of Golkar Party (2019). This research takes all of 50 news the corruption news from both actors listed in kompas.com.

This study used an analysis unit of reference, through which the researchers collected and calculated a set of words or sentences in accordance with predetermined categories. From Ware \& Linkugel (1973); Hearit (1995); Tollefson (2000); Hearit and Brown (2004); Glantz (2010); Heath and O'Hair (2010); Heath (2013); Kriyantono (2017); Jarvis (2016), the reference categories contained the types of apologia strategies: Denial, bolstering, differentiation and transcendence. Denial had the keywords: refusing, not guilty, not involved, unintentional action, and improper accusation; Bolstering had with the keywords: reminding people of positive contributions, reminding the many accomplishments, responsible but still connecting positive things and emphasizing positive nature to offset the allegations; Differentiation incorporated the keywords: redrawing the events of the crisis, reframing the accusations as positive, influencing people to see their actions from another perspective, asking the community to postpone its assessment until there is evidence; Transcendence included the keywords: define the accusations into the wider context, compare the allegations with the more important value so that the error rate will decrease, and put new facts which benefits him.

The experiment consisted of 100 participants from graduate and postgraduate students of communication science, Brawijaya University. The experiment was conducted after the researcher analysed content analysis findings. The research used the news contain bolstering statements from the actors as a result that content analysis revealed that most actors applied bolstering as dominant strategy. First, the participants were asked to read news containing the caught's bolstering statements, then, they were asked to fill the questionnaire of punitive responses. Second, they were asked to read news containing the suspects' bolstering statements, then, they were asked to fill the same questionnaire.

The questionnaire incorporates questions which were constructed from Jeong's (2009) punitive opinions and behaviours. Punitive opinions were measured by asking participants to indicate the extent to which they supported punishment of the actors. Response options ranged from no punishment (1) to severe punishment (7). Punitive behaviours were measured by asking: "would you be willing to boycott the corruption suspect' party?" Response options were ranged from strongly disagree (1) to strongly agree (7).

\section{RESULTS AND DISCUSSION}

There were 22 news related to the General Secretary of Golkar Party as corruption suspects who were not caught red-handed. In one news can be found more than one apologia strategy and more than one statement for one apologia strategy (Table 1).

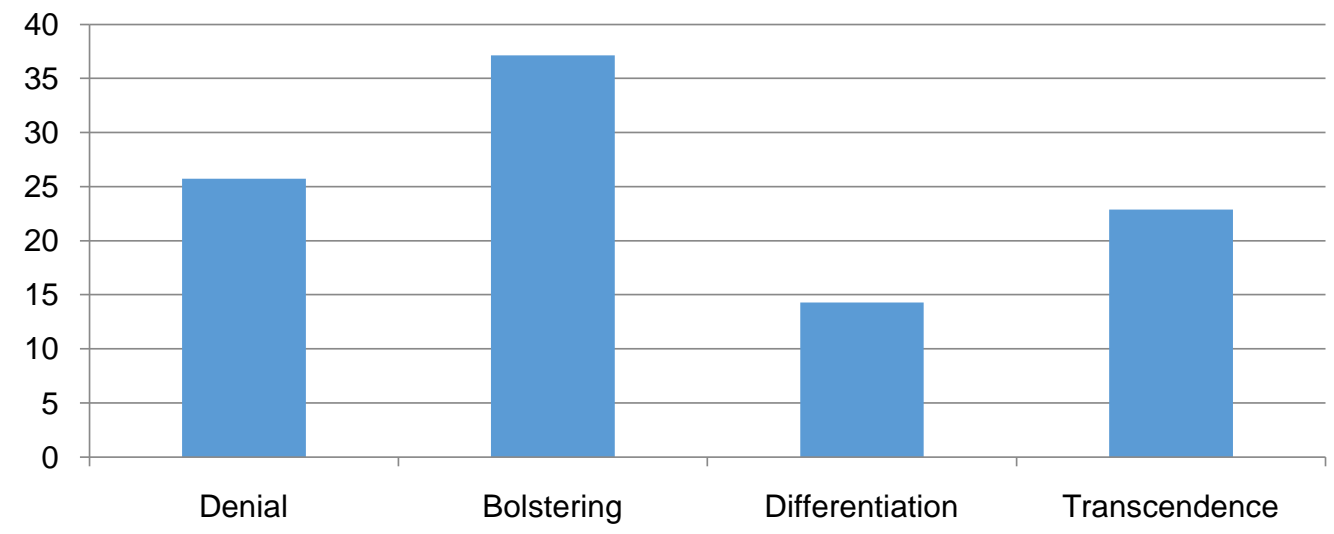

Figure 1 - Apologia Strategy of the General Secretary of Golkar Party, \% 
Although the General Secretary of Golkar Party is the actor who not caught redhanded, He focuses on bolstering strategy. Based on the Figure above, it can be seen in Kompas.com news related to the statements of the General Secretary of Golkar Party. It means that the actor tries to convince the public of having positive contributions, many accomplishments, and connecting positive things and emphasizing positive nature to offset the allegations. However, the actor also uses quite a lot of denial strategies where this strategy is the second most after the bolstering.

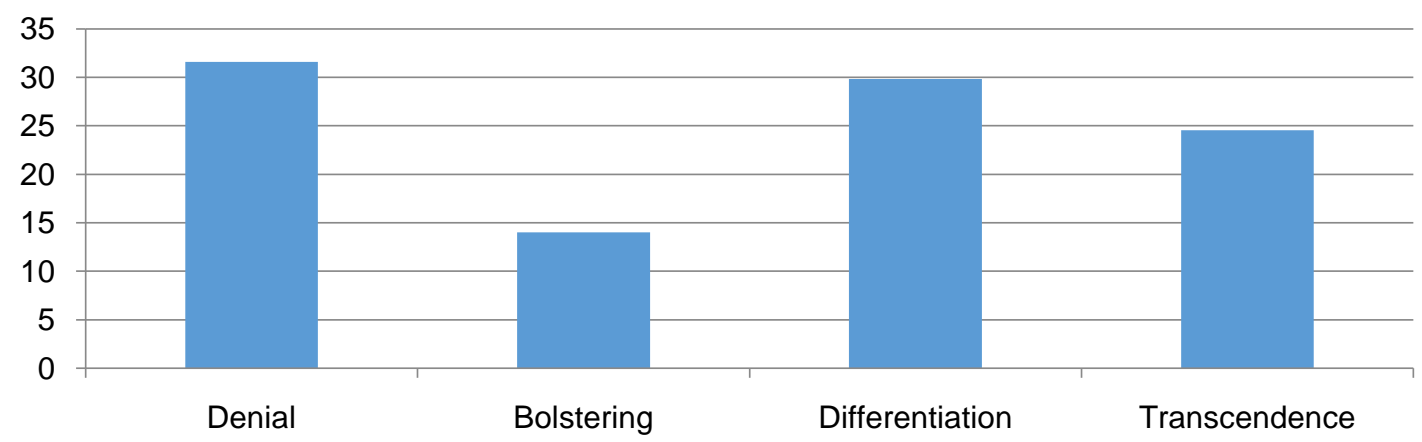

Figure 2 - Apologia Strategy of Apologia the chief of the United Development Party, \%

Figure 2 describes that the chief of the United Development Party uses the denial strategy as the main strategy. He placed the bolstering strategy as the least carried out strategy. From the findings of the data, it can be concluded that propositions one and two turned out to be unacceptable. Data shows the opposite, that is, suspects who are caught in a capture operation focus more on denial strategies and suspects who are caught not by hand capture are more focused on bolstering, not denial.

\section{RESULTS AND DISCUSSION}

The table below shows the results of experimental research between the news and suspected corruption cases that were caught in the capture operation and not. Researchers compared the level of tendency of public punishment against suspects based on the type of arrest and crisis management strategies used. The following researchers present the results of the comparison in the table below:

Table 1 - Comparison of Mean Scores of Apologia Corruption Experimental Research

\begin{tabular}{|c|c|c|c|c|}
\hline \multirow[b]{2}{*}{ No } & \multirow[b]{2}{*}{ Question } & \multirow{2}{*}{$\begin{array}{l}\text { Maximal } \\
\text { Score }\end{array}$} & \multicolumn{2}{|c|}{ Mean Score } \\
\hline & & & $\begin{array}{l}\text { Non } \\
\text { Apologia }\end{array}$ & Apologia \\
\hline 1 & $\begin{array}{l}\text { After reading the news that was presented to you, how big the } \\
\text { penalty scale must be received by the suspect or defendant of } \\
\text { corruption? }\end{array}$ & 7.00 & 6.12 & 5.76 \\
\hline 2 & $\begin{array}{l}\text { After reading the news presented to you, how big is the scale of your } \\
\text { trust in the suspect institution or the defendant of the corruption } \\
\text { case? }\end{array}$ & 7.00 & 3.00 & 2.66 \\
\hline 3 & $\begin{array}{l}\text { After reading the news presented to you, will you choose the party of } \\
\text { the suspect or defendant of the corruption case? }\end{array}$ & 7.00 & 1.98 & 2.94 \\
\hline 4 & $\begin{array}{l}\text { After reading the news presented to you, how big is the scale of your } \\
\text { anger to the suspect or defendant of corruption? }\end{array}$ & 7.00 & 5.00 & 5.18 \\
\hline 5 & $\begin{array}{l}\text { After reading the news presented to you, how large is your sympathy } \\
\text { to the suspect or defendant of corruption? }\end{array}$ & 7.00 & 2.26 & 2.5 \\
\hline
\end{tabular}

There are five questions compared in the table above. First, the researcher asked about the scale of punishment that must be received by suspects of corruption. The researcher placed seven scales to assess these things ranging from "punished" to "hugely heavy". All respondents said they agreed that the corruptors must be severely punished 
referring to the scale figures produced. It can be seen that the use of an apology strategy to deal with a crisis of corruption situation is quite effective. Corruption news that contains non apologia strategy shows a tendency for more punishment by the public than the news of corruption that contains apologia strategies. The dominance of the apology strategy in this context is bolstering.

The above results also apply to issues of trust in political parties from suspects and sympathy. The apologia strategy that is used is positively indicated by the results which state that the public is much more sympathetic to suspects who use apologia strategies. This also implies the choice of political party preferences by the public. The public also places much higher trust in political parties as suspects facing this crisis using an apologia strategy. Although the indicators of trust and sympathy are not on a good scale, but at least suspects who use an apologia strategy get higher sympathy and trust compared to suspects who do not use an apologia strategy.

This finding proves the third hypothesis that public tends to provide punitive opinions and behaviours for suspected who are arrested in hand arrest operations corruption cases. This assessment is certainly greatly influenced by the strategies used during the crisis. Referring to the results of this study, one way that can be used to suppress judgment and the tendency to punish by the public is to apply an apologia strategy. However, one thing that has not been able to overcome using this strategy is the level of public anger over acts of corruption committed by suspects.

Based on the results of the study, it was obtained data that alleged statements almost entirely used an apologia strategy. This shows that the statements of both direct and indirect sentences used by suspects and suspected corruptors are a form of apologia strategy in response to the accusations it receives. Heath (2013) explains that individuals and organizations may be criticized for their actions and the way they respond is a form of communication commonly known as apologia. Seeger and Sellnow (2016) also say that apologia describes the communication behaviour that occurs after a crisis or the accusations that lead to him happening. This communication behaviour attempts to explain what happened and improve and restore the reputation of image damage. In selecting messages for the public, the Apology Theory produces a premise that strategies used by individuals or organizations in responding to crises are adjusted to the specific situation faced, namely the types of accusations and facts that exist (Hearit. 1995; Botan \& Hazleton. 2006; Heath. 2013; \& Seager \& Sellnow. 2016).

The use of a non-dominant denial strategy is reinforced by the opinion of Coombs. Holladay \& Claeys (2016. p. 385) which states that denial is a strategy or claim subject to verification, "Denial should be effective only if the organization bears no responsibility for the crisis " Denial is effective for maintaining reputation during a crisis in certain scenarios or situations (Vand der meer. 2014). According to Towner (2009. p. 439). "A denial of an allegation or fact functions as a useful strategy (as long as the truth is not distorted) ..." Based on the situation and facts that exist according to the Apology Theory and supported by the opinion of Vand der Meer (2014) and Towner (2009).

Based on the above explanation, the corruptors who were not arrested in hand-arrest operations were not proven to tend to use denial strategies predominantly to maintain reputation during a crisis. Even so, the use of bolstering and differentiation strategies in suspected cases and suspected corruptors of government officials who are not arrested by hand arrest operations is not inappropriate to use because Glantz (2010) argues that bolstering is an effective strategy to improve one's image. In line with Glantz (2010), Harris (2006) also said that the statement of apology and accountability became a mandatory feature of legitimate and valid apologies in all languages and situations.

Pressure from the public and the media to admit mistakes makes companies use ambiguous messages to deny that they have done wrong but promised not to do it again (Hearit \& Brown, 2004; \& Kriyantono, 2014). Ware and Linkugel (1973) describe denial strategies and differentiation generally used to 'clear names'. The purpose of doing apologia is not to accept forgiveness (Hearit, 2006), but to avoid punishment and reputation damage (Lazare, 2004). 
The use of bolstering strategies that emphasize positive characteristics such as being responsible, apologizing, reminding of positive contributions and achievements that have been achieved in accordance with public relations activities as a communication technique, namely the organization or institution realizes that all organizational members have the potential to influence their image in the eyes public (Kriyantono, 2016).

\section{CONCLUSION}

Based on the results and discussion of the research described, it can be concluded that: the use of an apologia strategy in responding to a crisis or an assumption that attacks an individual is adjusted to the specific situation faced, namely the types of accusations and facts that exist. Based on the experimental research that has been done it can be concluded that the choice of strategies used to overcome the reputation crisis when corruption will affect public assessment. This is due to the fact that the public tends to give opinions and punishments to suspects in corruption cases caught. An apologia strategy such as bolstering in a situation like this will result in much higher sympathy than using a denial strategy. The use of bolstering strategies can also reduce the punitive behaviour of the community against suspects. Furthermore, even though they are not in a good position. The suspects who use bolstering strategies can have more positive implications for political parties or institutions of origin than the suspect compared to suspects who use the denial strategy. Although this strategy cannot reduce the tension of public anger due to acts of corruption that have been committed. This strategy can only manage the reputation of the suspects.

\section{REFERENCES}

1. Arendt. C., LaFleche, M., \& Limperopulos. M. A. (2017). A qualitative meta-analysis of apologia image repair and crisis communication: Implications for theory and practice. Public Relations Review. 43. 517-526.

2. Benoit. W. L. (1995). Sears's repair of its auto service image: Image restoration discourse in the corporate sector. Communication Studies. 46. 89-105.

3. Chikudate. N. (2010). Reinterpreting corporate apologia as self-discipline. Corporate Communication: An International Journal. 15(4). 397-409.

4. Coombs. W. T. (2015). Ongoing crisis communication: Planning, managing, and responding. California: Sage.

5. Coombs. W. T., \& Holladay. S. J. (2011). An exploration of the effects of victim visuals on perceptions and reactions to crisis events. Public Relations Review. 37. 115-120.

6. Coombs. W. T.. Frandsen. F.. Holladay. S. J.. \& Johansen. J. (2010). Why a concern for Apologia and crisis communication?. Corporate communications: An International Journal. 15(4). 337-349. doi: 10.1108/13563281011085466.

7. Coombs. W.T. (2010). Crisis communication and its allied fields. In Coombs. W. T.. \& Holladay. S. J. (Eds.). Handbooks in communication and media: The handbook of crisis communication (pp. 54-64). United Kingdom: Blackwell Publishing.

8. Downey, S. D. (1993). The evolution of the rhetorical genre of Apologia. Western Journal of Communication, 57, 42-64.

9. Fauzi, A. (2017). "Kompas.com" Raih Penghargaan di Ajang "Wow Brand Award" 2017. Diperoleh dari: http://bisniskeuangan.kompas.com/read/2017/03/09/ 173406526/.kompas.com.raih.penghargaan.di.ajang.wow.brand.award.2017

10. Fearn-Banks. K. (2017). Crisis communications: A casebook approach. New York: Routledge.

11. Glantz, M. (2010). The Floyd Landis doping scandal: Implications for image repair discourse. Public Relations Review, 36, 157-163. doi:10.1016/ j.pubrev.2009.09.002.

12. Harris S., Grainger, K. \& Mullany, L. (2006). The pragmatics of political apologies. Discourse and Society, 17(6), 715-37. doi: 10.1177/0957926506068429 
13. Hearit, K. M. (1992). Organizations, Apologia, and crises of social legitimacy (Doctor of Philosophy, Purdue University. Di akses di Proquest.

14. Hearit, K. M. (2005). Apologia. In Heath, R. L. (Ed.). Encyclopedia of public relations. California: Sage Publications, Inc.

15. Hearit, K. M. (2006). Crisis management by apology: Corporate response to allegations of wrongdoing. New Jersey: Lawrence Erlbaum Associates.

16. Hearit, K. M., \& Brown, J. (2004). Merrill lynch: Corporate Apologia and business fraud. Public Relations Review, 30, 459-466, doi: 10.1016 /j.pubre v.2004 .08.008

17. Heath, R. L. (Ed.) (2013). Encyclopedia of public relations (Vols. 1-2). Thousand Oaks, CA: SAGE Publications Ltd. doi: 10.4135/9781452276236.

18. Heath, R. L., \& O'Hair, H. D. (2009). Handbook of Risk and Crisis Communication. New York: Routledge.

19. Hoffmann. N. C., \& Barnett. B. A. (2015). Apologia and rape: How the US military framed two cases of sexual assaults. Media Report to Women. 43(4). 6-23.

20. Ika, A. (2016). Kompas.com, Jadi "Top Brand" Kategori "Online News Platform" Pilihan Generasi Y. Diperoleh dari: http:// bisniskeuangan. kompas.com/read/2016/09/26/195450726/kompas.com.jadi.top.brand.kategori. online.news.platform.pilihan.generasi.y

21. Kiambi, D. (2011). Ethnic appeal: A self-defense tool for kenyan politicians. Public Relations Review, 38, 144- 146. doi:10.1016/j.pubrev.2011.08.019

22. Kriyantono. R.. \& McKenna. B. (2017). Developing a culturally-relevant public relations theory for Indonesia. Malaysian Journal of Communication. 33(1). 1-16.

23. Kriyantono, R., Destrity, N. A., Amrullah, A. A., \& Rakhmawati, F. Y. (2017). Management of public relations for supporting the anti-corruption national program in Indonesia. International Journal of Applied Business \& Economic Research, 15(20), 293-303.

24. Kriyantono, R. (2017). Teori public relations barat \& lokal: Aplikasi penelitian dan praktik. Jakarta: Kencana.

25. Kriyantono, R. (2016). PR writing: Teknik produksi media public relations dan publisitas koorporat. Jakarta: Kencana.

26. Kriyantono, R., Riani, Y. A., \& Savitri, R. I. (2017). Public's attribution vs punitive behavior

27. in Indonesian public relations practice. Jurnal IImu Komunikasi, 14(1), 43-60.

28. Kriyantono, R. (2015). Public relations \& crisis management : Pendekatan critical public relations, etnografi kritis \& kualitatif. Jakarta: Kencana.

29. Kriyantono, R., Ramadlan, M. F., \& Setiawan, A. (2015). Hidden advertising in local election era: Reducing the public's right of information and critical power of media in Indonesia. International Journal of Development Research, 5(10), 5875-5880.

30. Kriyantono, R. (2012). Measuring A Company Reputation in A Crisis Situation: An Ethnography Approach on The Situational Crisis Communication Theory, International Journal of Business and Social Science, 3(9).

31. Lazare, A. (2004). On apology. New York: Oxford University Press.

32. Lehmberg. D.. \& Hicks. J. (2018). A 'glocalization' approach to the internationalizing of crisis communication. Business Horizons. 61. 357-366.

33. Pratama, B.I., Kriyantono., \& Susanti, F.N. (2017). Identifying local wisdom in elementary school anti-corruption education Malang. RJOAS, 8(68), 131-142.

34. Roberson. K. M., \& Connaughton, S. L. (2010). On the presidential campaign trail: Apologia of association. Public Relations Review. 36. 181-183.

35. Seeger. M. \& Sellnow. T. (2016). Apologia theory. In C. Carroll (Ed.). The SAGE encyclopedia of corporate reputation (Vol. 2. h. 39-40). Thousand Oaks.. CA: SAGE Publications Ltd. doi: 10.4135/9781483376493.n21.

36. Stewart, C. (2008). Lessons learned: How jet jet blue airways used Apologia and new media to survive crisis-a case study (Doctoral Thesis, School of Communication and the Arts Regent University).

37. Taneja. S.. Pryor. M.G.. Sewell. S.. \& Recuero. A.M. (2014). Strategic crisis management: A basis for renewal and crisis prevention. Journal of Management Policy and Practice. 15(1). 78-85. 
38. Tapsell, R. (2015). Platform convergence in Indonesia: Challenges and opportunities for media freedom. Convergence: The International Journal of Research into New Media Technologies, 21(2), 182-197.

39. Tollefson, M. M. (2000). "Anonymous" joe klein and newsweek: Individual and corporate Apologia. Communication Quarterly, 48(1), 58-64.

40. Toriana, L. (2017). Corruption Perception Index 2016: Terus Perkuat Integritas Sektor Publik, Dorong Integritas Bisnis Sektor Swasta. Diakses dari: www.ti.or.id/index.php/publication/2017/01/25/corruption-perceptions-index-2016

41. Ware, B. L., Linkugel, W. A. (1973). They spoke in defense of themselves: On the generic criticism of Apologia. Quarterly Journal of Speech, 59, 273-83.

42. Waymer, D., \& Heath, R. L. (2007). Emergent agents: The forgotten publics in crisis communication and issues management research. Journal of Applied Communication Research, 35(1), 88-108

43. Weiner. B. (2006). Social motivation, justice, and the moral emotions: An attributional approach. New Jersey: Lawrence Erlbaum Associates. Inc. 